\title{
Les musées d'agriculture dans le monde et en France
}

\section{François Sigaut}

\section{(2) OpenEdition}

\section{Journals}

Édition électronique

URL : https://journals.openedition.org/tc/1014

DOI : $10.4000 /$ tc. 1014

ISSN : 1952-420X

Éditeur

Éditions de l'EHESS

\section{Édition imprimée}

Date de publication : 1 juin 1984

ISSN : 0248-6016

\section{Référence électronique}

François Sigaut, «Les musées d'agriculture dans le monde et en France », Techniques \& Culture [En ligne], 3 | 1984, mis en ligne le 26 janvier 2006, consulté le 29 septembre 2022. URL : http:// journals.openedition.org/tc/1014; DOI : https://doi.org/10.4000/tc.1014

Ce document a été généré automatiquement le 29 septembre 2022

Tous droits réservés 


\title{
Les musées d'agriculture dans le monde et en France
}

\author{
François Sigaut
}

